\title{
Determination of Meloxicam in Pharmaceutical Formulation by Azo-Coupling Reaction with Sulphanilic Acid Using Both Batch and Flow- Injection Technique
}

\author{
Shirwan O. Baban \\ Aveen F. Jallal \\ Department of Chemistry \\ College of Education/ Scientific Departments \\ University of Salahaddin \\ Hawler / Iraqi Kurdistan Region
}

(Received 6/6/2011; Accepted 26/9/2011)

\begin{abstract}
Two sensitive and fast spectrophotometric methods were used by batch and flowinjection spectrophotometric techniques for the determination of meloxicam are proposed. The methods were based on azo-coupling reaction of meloxicam with sulphanilic acid in the presence of sodium nitrite in alkaline medium after converted to primary aromatic amine. The calibration curves resulting from measuring the absorbance at $365 \mathrm{~nm}$ are linear over the ranges $1.0-20$ and $3.0-30 \mu \mathrm{g} / \mathrm{ml}$ with detection limits of 0.5 and $1.0 \mu \mathrm{g} / \mathrm{ml}$, respectively. The molar absorptivity and Sandell index were $1.3839 \times 10^{4} 1 / \mathrm{mol} . \mathrm{cm}$ and $2.539 \times 10^{-2} \mu \mathrm{g} / \mathrm{cm}^{2}$ respectively. The methods are applied to the routine analysis of meloxicam in pharmaceutical formulations.
\end{abstract}

Keywords: Meloxicam; sulphanilic acid; sodium nitrite, hydrochloric acid, sodium carbonate; flow-injection technique; spectrophotometry; pharmaceuticals (tablet).

\section{فير الميلوكسيكلفي المستحضرل الصيدلنية بولملة فالى آزو الأزولجي مع سافلنيلك أسيد بالالرقة الهلاسكية و قعنية الهقن الجرباني}

\section{الملغص}

يتناول هذه البمثطريقتن طيفيتينسريعتين و مسلستين بلستخدلم ألطريقه الكلالسيكية وقفنيه الحق نـ

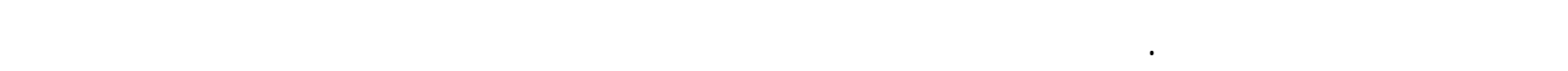

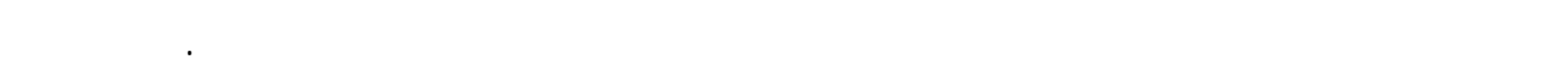

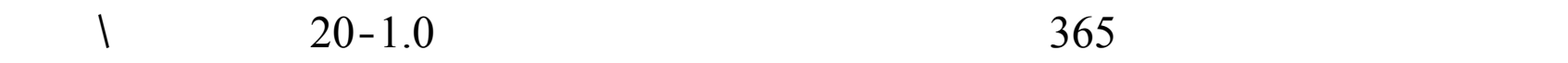

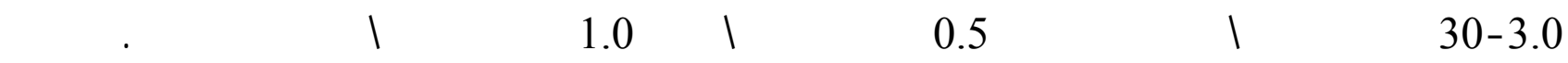

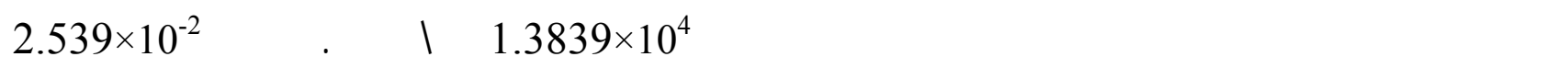




\section{مايكروغرلهابم² على الترتيب للطريقة الكلاسيكيه. و مق قبيق هذة الطريق ـة لتحلي لل الميلوك سيكلم ف مي المستحضرك الصيدلانية.}

\section{INTRODUCTION}

Chemically, meloxicam is 4-hydroxy-2-methyl-N-(5-methyl-2-thiazoly)-2H-1,2benzo-thiazine-3-carboxamide-1,1dioxide with chemical formula $\left(\mathrm{C}_{14} \mathrm{H}_{13} \mathrm{~N}_{3} \mathrm{O}_{4} \mathrm{~S}_{2}\right)$ and molecular weight $351.4 \mathrm{~g} / \mathrm{mol}$. (Fig.1) commonly prescribed as non-steroidal antiinflammatory drug with analgesic and antipyretic properties. Prostaglandins are substances that contribute to inflammation of joints. Meloxicam inhibits prostaglandin synthetase (cyclooxygenase 1 and 2) and leads to a decrease of the synthesis of prostaglandins; therefore, inflammation is reduced (British pharmacopeia, 2009). Many methods are reported for the determination of meloxicam by spectrophotometry (Garcia et al., 2000; Zawilla et al., 2003; Nemutlu and Kır, 2004; Taha et al., 2006; Basu et al., 2009; Sawant et al., 2010), turbidimetry (Murarasu et al., 2010), FI-chemiluminescence (Liu et al., 2005; M. Al-Kindy et al., 2010), liquid chromatography (Nemutlu et al., 2007), HPLC and RP-HPLC (Arayne et al., 2005; Sinha et al., 2009). HPLC is the technique that most commonly used for the determination of meloxicam (Zhang and Hoo-Kyun Choi, 2008; Bandarkar and Vavia, 2009). It confirms that the analytical procedure employed for the analysis is suitable and reliable for its intended use. In present study, all validation parameters for quantitative analysis of meloxicam in pharmaceutical formulation were tested.<smiles>Cc1cnc(NC(=O)C2=C(O)c3ccccc3S(=O)(=O)N2C)s1</smiles>

Fig.1: Structure of meloxicam

\section{Experimental}

\section{Apparatus}

\section{Flow injection system}

Fig.2 shows the schematic diagram of FIA system used for Flow-injection spectrophotometric determination of meloxicam. The system consists of:

a. Multi channel peristaltic pump (Watson-Marlow 5012) was used to propel the buffer and reagent solution.

b. Six-way injection valve with various sample loops, used to inject the sample into the buffers carrier stream (FIA lab company)

c. Detector, Jenway $6300 \mathrm{UV}$-Visible spectrophotometer with a flow cell of $10 \mathrm{~mm}$ path length made of quartz.

d. Recorder, LKB2210 2-channel. 


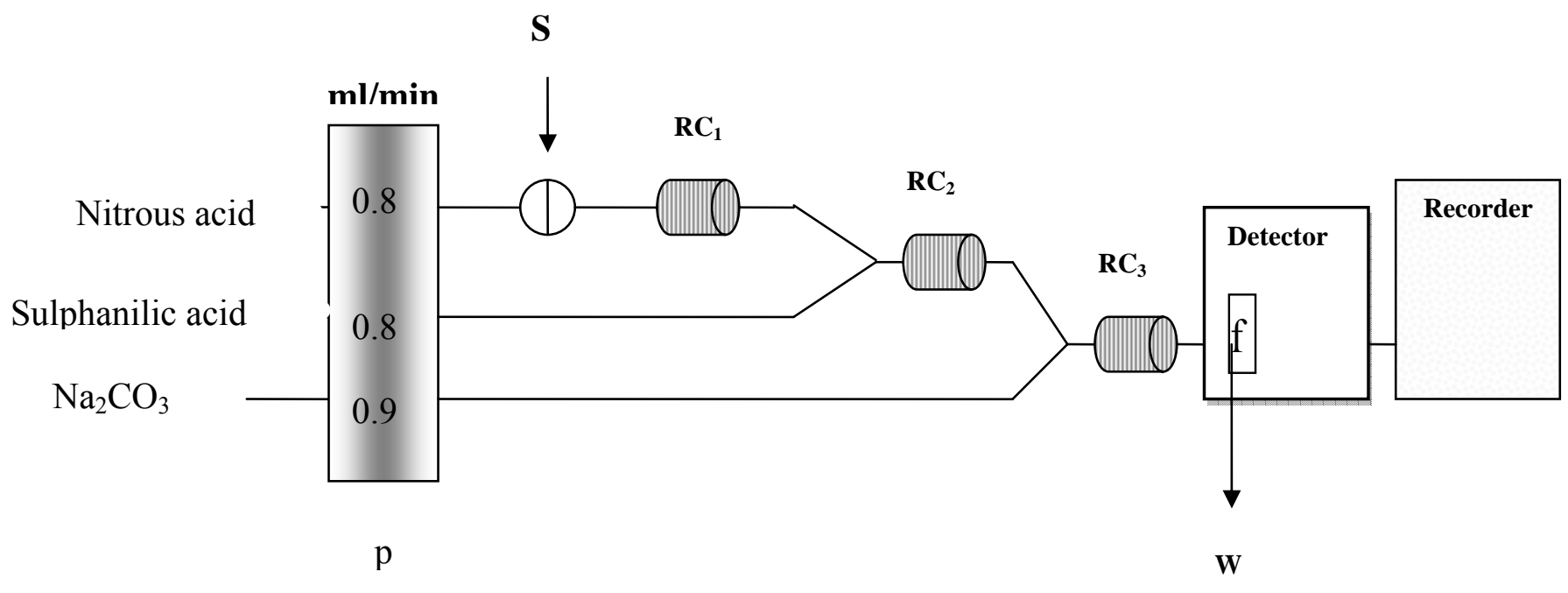

Fig.2: FI manifold used for determination of meloxicam by diazotization method: (p) pump, (S) sample injected $(\mu \mathrm{l}),(\mathrm{RC})$ reaction coils, (f) flow cell, and $(\mathrm{W})$ waste.

\section{Reagents}

All chemicals used were of analytical reagent grade and distilled water was used throughout the experiments.

Stock solution of meloxicam $(100 \mu \mathrm{g} / \mathrm{ml}): 0.01 \mathrm{~g}$ of meloxicam was transferred into a $100 \mathrm{ml}$ conical flask, $20 \mathrm{ml}$ of $2.0 \mathrm{M}$ sodium hydroxide solution was added and heated in a boiling water bath for $30 \mathrm{~min}$, after cooling the $\mathrm{pH}$ was adjusted to a 9.0 by adding appreciate amount of $2.0 \mathrm{M}$ hydrochloric acid then transferred to $100 \mathrm{ml}$ volumetric flask and volume completed to $100 \mathrm{ml}$ with distilled water, working standard solution $(16 \mu \mathrm{g} / \mathrm{ml})$ was prepared by diluting a suitable volume of stock solution ${ }^{(6)}$.

Sodium hydroxide solution (2.0 M): $4.0 \mathrm{~g}$ of sodium hydroxide was dissolved in distilled water and the volume was completed to $50 \mathrm{ml}$.

Sodium nitrite solution (1.0\%): $1.0 \mathrm{~g}$ of sodium nitrite was dissolved in distilled water and the volume was completed to $100 \mathrm{ml}$.

Hydrochloric acid solution (0.5 M) and (2.0 M): was prepared by dilution of concentrated hydrochloric acid (36\%) with distilled water.

Sulphanilic acid solution (0.1\%): $0.1 \mathrm{~g}$ of Sulphanilic acid was dissolved in distilled water and the volume was completed to $100 \mathrm{ml}$.

Sodium carbonate solution (0.5 M): $5.30 \mathrm{~g}$ of sodium carbonate was dissolved in distilled water and the volume was completed to $100 \mathrm{ml}$.

\section{Sample preparation}

Ten tablets of meloxicam were grounded to fine powder and mixed thoroughly. A portion of the powder was weighed accurately, transferred into a $50 \mathrm{ml}$ volumetric flask; $40 \mathrm{ml}$ of acetone was added and shaken for 30min in shaker water bath. The volume was diluted to the mark with acetone then the solution was mixed and filtered. A $25 \mathrm{ml}$ of filtered solution was transferred into $100 \mathrm{ml}$ conical flask and to the conical flask evaporated in a boiling water bath to dryness, after that previous procedure for stock solution was applied for meloxicam determination (Taha et al., 2006). 


\section{Batch method}

\section{RESULTS AND DISCUSSION}

\section{Preliminary investigation}

Four milliliters of $100 \mu \mathrm{g} / \mathrm{ml}$ meloxicam solution was added to a $25 \mathrm{ml}$ volumetric flask, $1.5 \mathrm{ml}$ of $1.0 \%$ sodium nitrite solution, $0.5 \mathrm{ml}$ of $0.5 \mathrm{M}$ hydrochloric acid, $5 \mathrm{ml}$ of $0.1 \%$ sulphanilic acid solution and $2.0 \mathrm{ml}$ of $0.5 \mathrm{M}$ sodium hydroxide were added. The solution was diluted to the mark with distilled water and the absorbance of the final solution was measured at $365 \mathrm{~nm}$ using $1.0-\mathrm{cm}$ quartz cell against reagent blank, which was prepared in the same way except that it doses not contain meloxicam.

\section{Optimization of experimental parameters}

Each spectrophotometric method has its optimum conditions, therefore different variable condition were investigated to obtain optimum condition; for measurements.

\section{Absorption spectra:-}

The absorption spectra for possible formed azo compound and the blank are shown in Fig. 3. The azo compound shows maximum absorbance at $365 \mathrm{~nm}$ with non-significant absorbance of the blank at this wavelength as shown below. The apparent $\lambda_{\max }$ was suspected because most the azo compounds give yellow, orange and red colours.

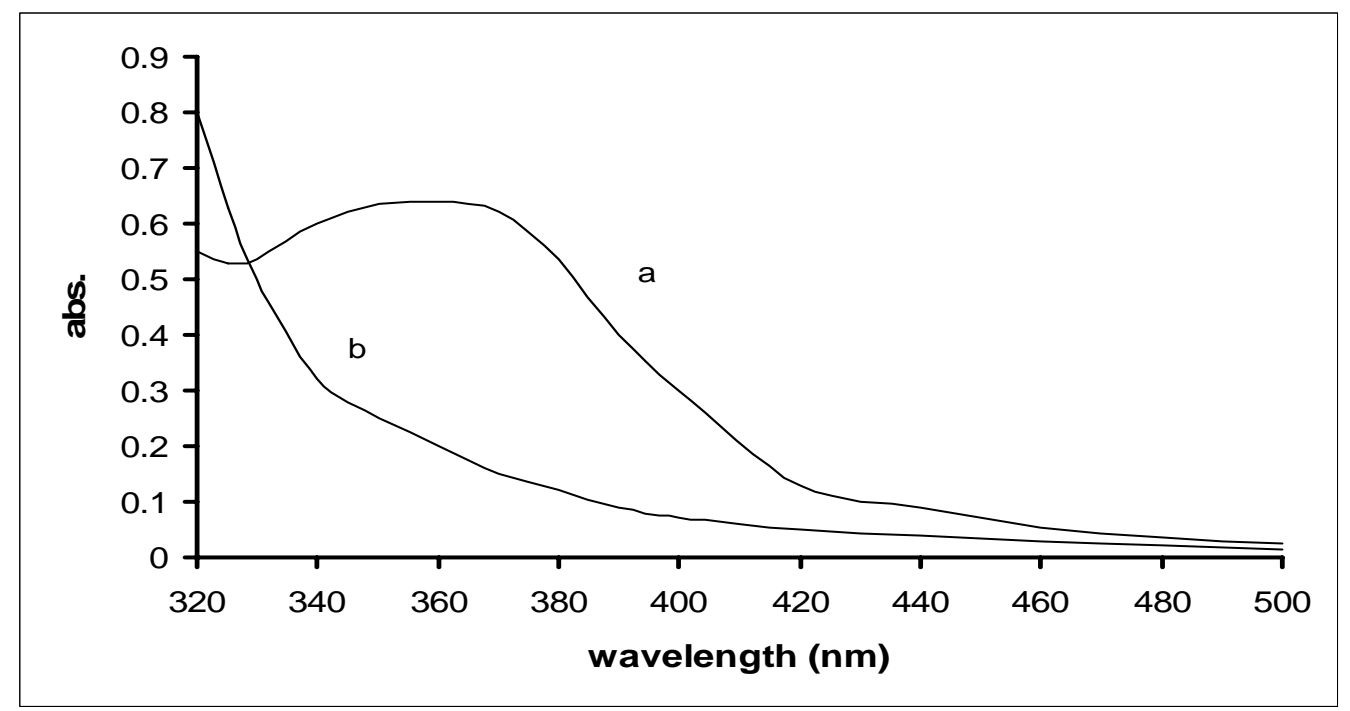

Fig. 3: The spectra of (a) produce azo compound against blank (b) the blank solution against distilled water.<smiles>Cc1cnc(NC(=O)C2=C(O)c3ccccc3S(=O)(=O)N2C)s1</smiles>

Meloxicam

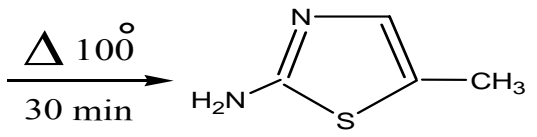

2AMT 
<smiles></smiles>

2AMT<smiles>CCc1cnc(N=Nc2cc(S(=O)(=O)O)cc(C)c2N)s1</smiles>

Diazonium ion

Sulphanilic acid

yellow compound

\section{Effect of sodium nitrite amount}

Nitrite ion is an essential participitant in the diazotization reaction. Therefore, the effect of the volume of $1.0 \%$ sodium nitrite solution on the colour intensity was investigated as shown in Fig. 4. The absorbance increased by increasing volume of sodium nitrite added in the range of 0.5 to $2.0 \mathrm{ml}$ and then slightly decreased at higher volumes. Therefore, $2.0 \mathrm{ml}$ of sodium nitrite was applied in subsequent reactions because it gave higher absorbance.

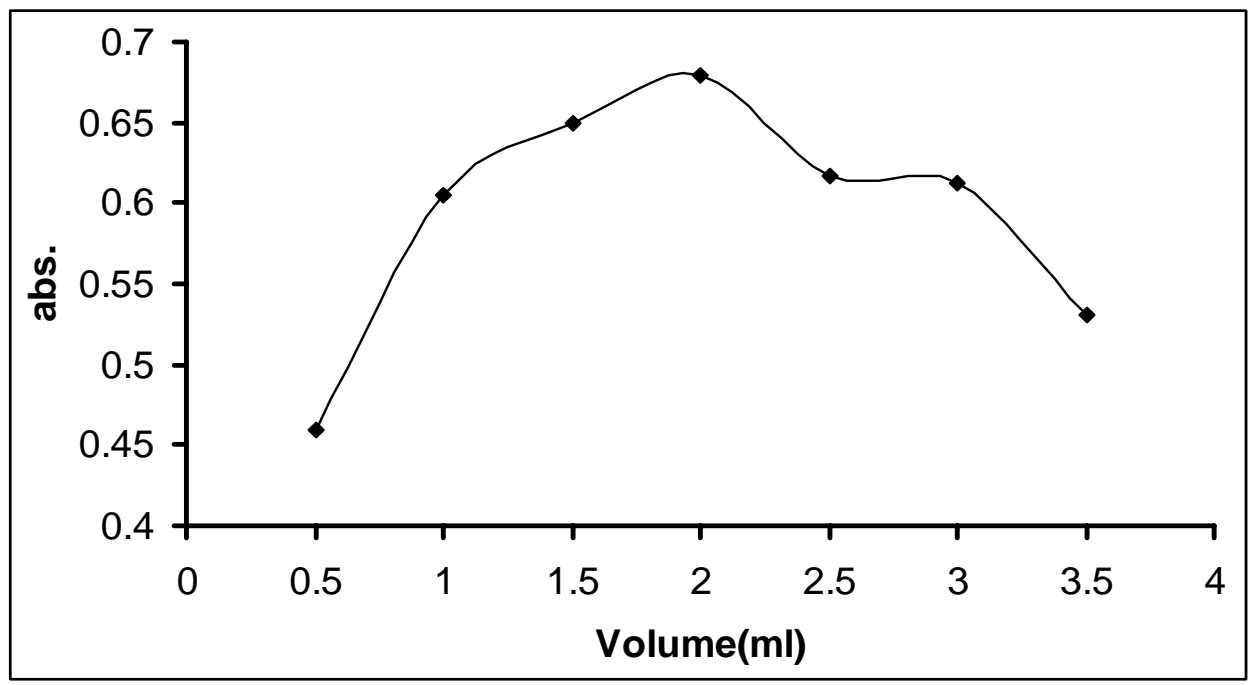

Fig. 4: Effect of $1.0 \%$ sodium nitrite volumes on the absorbance intensity.

\section{Effect of acids}

Different types of acids viz hydrochloric acid, sulphuric acid, nitric acid, and acetic acid have been tested for maximum absorption achievement as shown in Table 1. Hydrochloric acid gave the best results in contrast with other acids. Effect of hydrochloric acid volumes on absorbance is shown in Fig. 5. The colour intensity increased with increasing 
hydrochloric acid volumes up to $0.6 \mathrm{ml}$, after which the colour intensity start to decrease. Therefore, $0.6 \mathrm{ml}$ of $0.5 \mathrm{M}$ hydrochloric acid was used for further work.

Table 1: Effect of different type of acids.

\begin{tabular}{|c|c|}
\hline Acid types (0.5M) & Absorbance \\
\hline $\mathrm{HCl}$ & 0.641 \\
\hline $\mathrm{H}_{2} \mathrm{SO}_{4}$ & 0.536 \\
\hline $\mathrm{HNO}_{3}$ & 0.554 \\
\hline $\mathrm{CH}_{3} \mathrm{COOH}$ & 0.540 \\
\hline
\end{tabular}

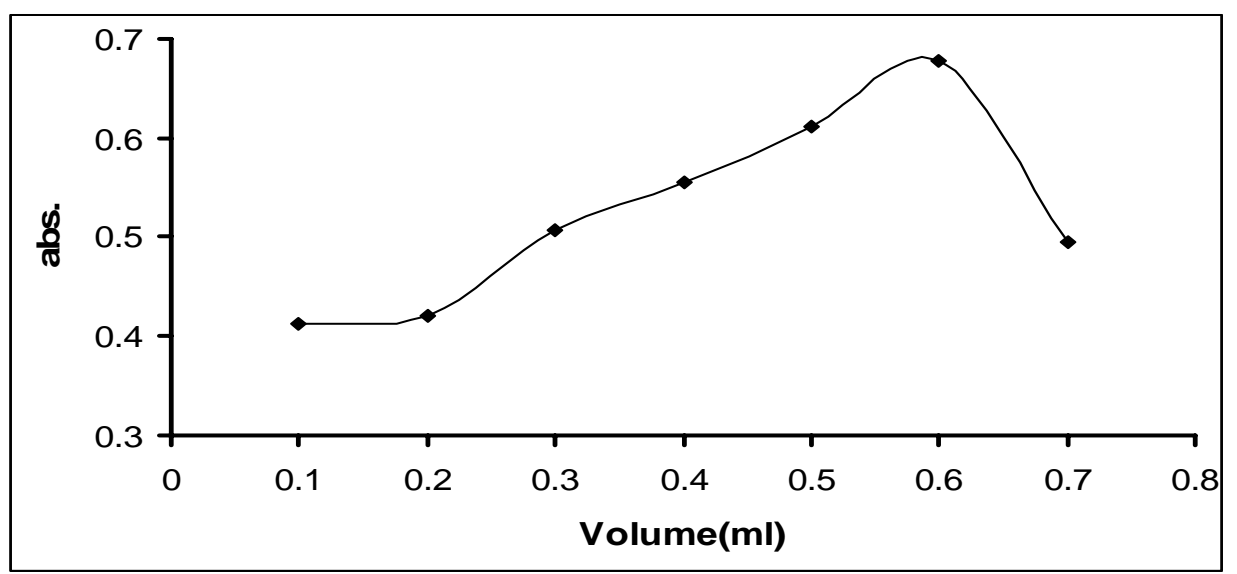

Fig. 5: Effect of $0.5 \mathrm{M}$ hydrochloric acid volumes on colour intensity.

\section{Effect of sulphanilic acid}

The absorbance increased with increasing the added volume of $0.1 \%$ sulphanilic acid solution up to $6.0 \mathrm{ml}$, after which the absorbance starts to decrease. Therefore, $6.0 \mathrm{ml}$ of $0.1 \%$ sulphanilic acid was used for subsequent work. The solubility of sulphanilic acid is $0.1 \mathrm{~g}$ in $100 \mathrm{ml}$ distilled water; therefore the added volume could not be reduced. Fig.6. shows the effect of sulphanilic acid volumes on the absorbance of the system.

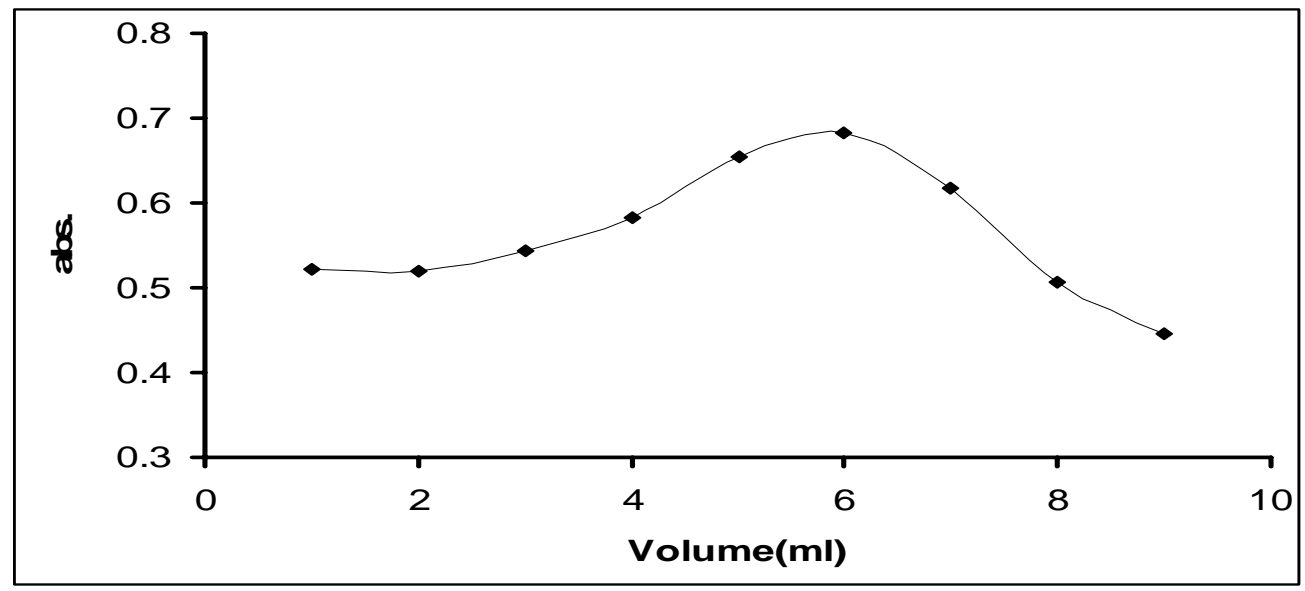

Fig. 6: Effect of the volume of Sulphanilic acid solution on the absorbance of the system 


\section{Effect of alkaline solution}

Azo dye colours usually appear in alkaline media. The effects of different alkaline mediums were tested $(0.5 \mathrm{M}$ of sodium hydroxide, sodium carbonate and potassium hydroxide). The result shows that $2.0 \mathrm{ml}$ of $0.5 \mathrm{M}$ sodium carbonate solution gave maximum absorption among other bases as shown in Table 2. Fig. 7. shows effect of different volumes of $0.5 \mathrm{M}$ sodium carbonate on the colour intensity.

Table 2: Effect of different type of bases.

\begin{tabular}{|c|c|}
\hline Base types (0.5M) & Absorbance \\
\hline $\mathrm{NaOH}$ & 0.576 \\
\hline $\mathrm{Na}_{2} \mathrm{CO}_{3}$ & 0.638 \\
\hline $\mathrm{KOH}$ & 0.602 \\
\hline
\end{tabular}

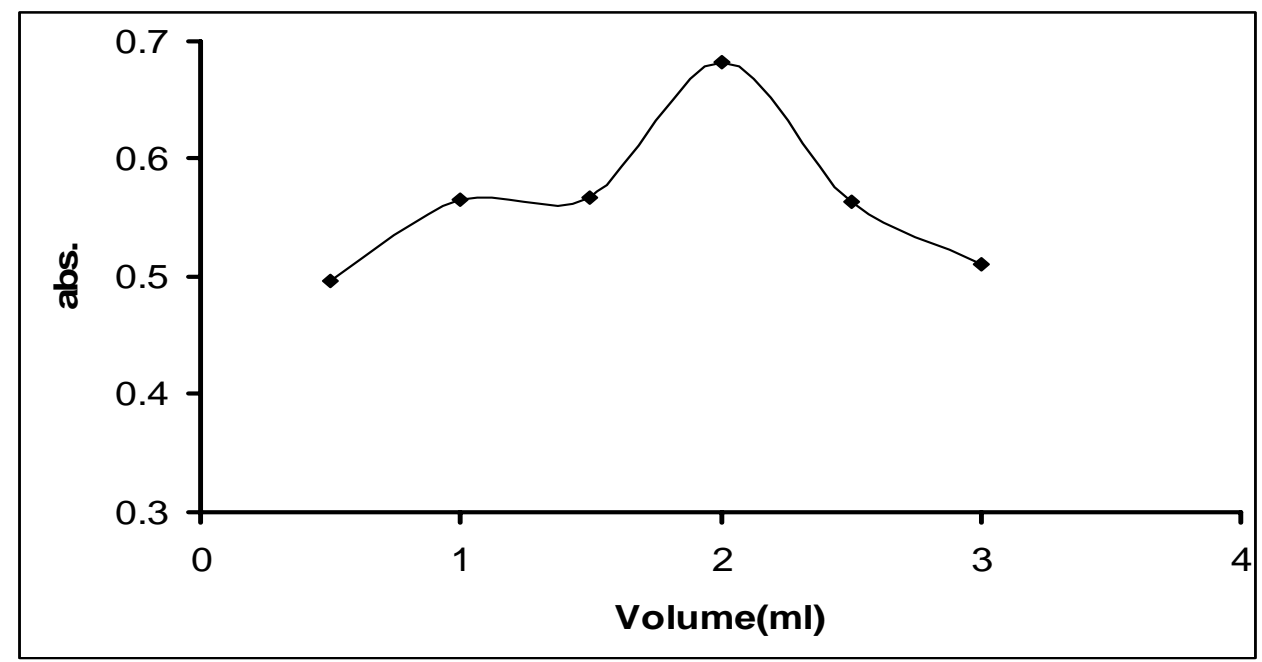

Fig. 7: Effect of the volume of $0.1 \% 0.5 \mathrm{M}$ of sodium carbonate of solution on the absorbance of the system.

\section{Calibration curve}

The calibration curve in Fig. 8 obtained by recommended procedure showed good linearity over the concentration range $1.0-20 \mu \mathrm{g} / \mathrm{ml}$ for meloxicam. Table 3 shows the optical characteristics of the propose method. 


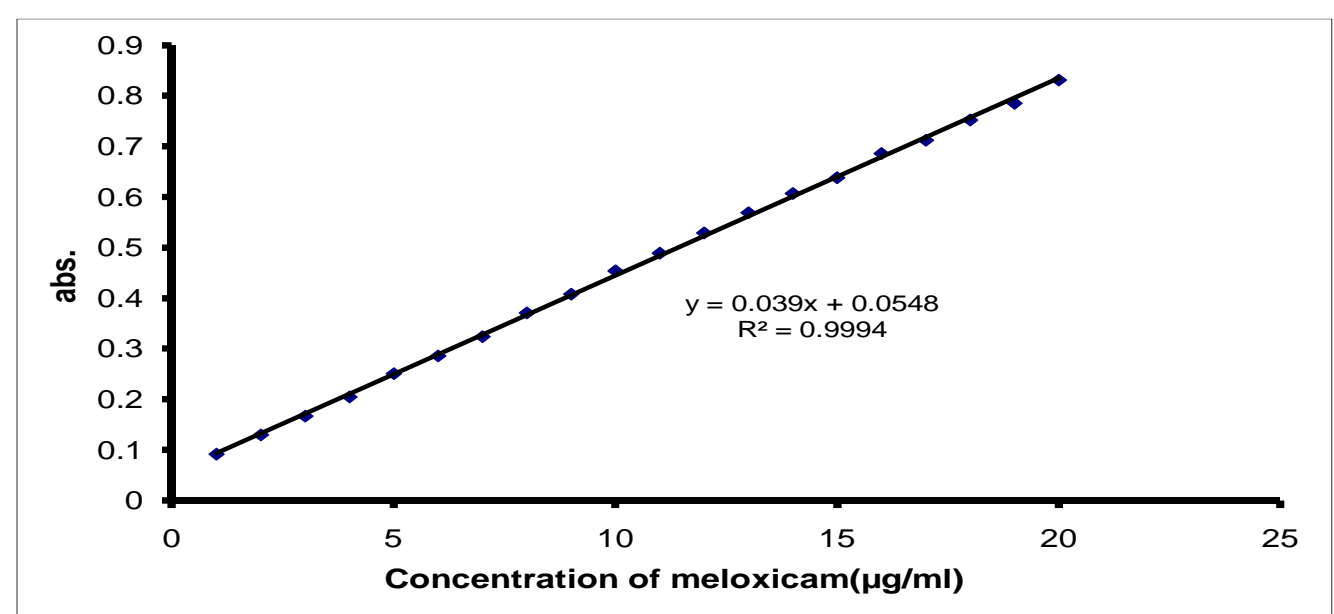

Fig. 8: Calibration curve for spectrophotometric determination of meloxicam by coupling with sulphanilic acid.

Table 3: Optical characteristics of the method for determination of meloxicam.

\begin{tabular}{|c|c|}
\hline Parameter & Character \\
\hline Colour & pale - Yellow \\
\hline$\lambda \max (\mathrm{nm})$ & 365 \\
\hline Beer's law $(\mu \mathrm{g} / \mathrm{ml})$ & $1.0-20$ \\
\hline Molar absorptivity $(1 / \mathrm{mol} . \mathrm{cm})$ & $1.3839 \times 10^{4}$ \\
\hline Sandell index $(\mu \mathrm{g} / \mathrm{ml})$ & $2.539 \times 10^{-2}$ \\
\hline Correlation coefficient $(\mathrm{r})$ & 0.9996 \\
\hline Detection limit $(\mu \mathrm{g} / \mathrm{ml})$ & 0.1 \\
\hline
\end{tabular}

\section{Precision and accuracy}

The precision and accuracy of the method were checked depending on values of relative standard deviation (RSD \%) and relative error percent (Erel \%) for five repetitive determination of meloxicam at three different concentration levels. Table 4 shows the accuracy and precision data.

Table 4: Accuracy and precision data of the batch method.

\begin{tabular}{|c|c|c|c|}
\hline Meloxicam conc.( $\mathbf{\mu g} / \mathbf{m l})$ & SD & RSD\% & E $_{\text {rel }} \%$ \\
\hline 2.0 & 0.00305 & 2.335 & -3.59 \\
\hline 10 & 0.00449 & 0.9894 & 2.35 \\
\hline 18 & 0.00152 & 0.2015 & -0.68 \\
\hline
\end{tabular}

\section{Flow injection procedure \\ Preliminary investigation}

The FI manifold shown in Fig. 2 was used for determination of meloxicam. Nitrous acid $\left(1 \% \mathrm{NaNO}_{2}\right.$ in $\left.0.5 \mathrm{M} \mathrm{HCl}\right), 0.025 \%$ sulphanilic acid and $0.2 \mathrm{M}$ sodium carbonate solutions were propelled at flow rates $0.9,0.8,1.2 \mathrm{ml} / \mathrm{min}$ respectively using multi-channel peristaltic pump. $100 \mu \mathrm{l}$ meloxicam solution sample was injected to react with nitrous acid solution in the $20 \mathrm{~cm}$ reaction coil. The formed diazonium ion was reacted with $0.025 \%$ 
sulphanilic acid solution in the reaction coil $40 \mathrm{~cm}$ and then with sodium carbonate solution in a reaction coil of $80 \mathrm{~cm}$ to form coloured azo compound. The peak heights were recorded at $365 \mathrm{~nm}$.

\section{Optimization of conditions}

Table 5 shows the physical and chemical optimization for the method.

\section{Calibration curve}

The calibration curve was constructed using the optimum conditions (Table 5), the calibration curve was linear in the concentration range 3.0-30 $\mu \mathrm{g} / \mathrm{ml}$ meloxicam as shown in Fig. 9, with the detection limit $1.0 \mu \mathrm{g} / \mathrm{ml}$. Table 6 shows the statistical data for the proposed method.

Table 5: Physical and chemical optimization for spectrophotometric determination of meloxicam with sulphanilic acid in alkaline medium using Flow -injection system.

\begin{tabular}{|c|c|c|c|c|c|c|c|c|c|c|}
\hline $\begin{array}{c}\text { Optimize } \\
\text { parameter }\end{array}$ & \multicolumn{2}{|c|}{ Variables } & \multicolumn{8}{|c|}{ Measurement } \\
\hline \multirow{14}{*}{ 矛 } & \multirow{2}{*}{$\begin{array}{l}\text { Nitrous acid } \\
\text { flow rate }\end{array}$} & $\mathrm{ml} / \mathrm{min}$ & 0.3 & 0.6 & 0.7 & $0.8 \#$ & 0.9 & 1.2 & & \\
\hline & & p.h(cm) & 2.4 & 2.96 & 3.65 & 4.98 & 4.65 & 4.01 & & \\
\hline & \multirow{2}{*}{$\begin{array}{l}\text { Sulphanilic } \\
\text { acid flow rate }\end{array}$} & $\mathrm{ml} / \mathrm{min}$ & 0.3 & 0.6 & 0.7 & 0.8\# & 0.9 & 1.2 & & \\
\hline & & p.h $(\mathrm{cm})$ & 2.81 & 3.61 & 4.11 & 5.28 & 4.68 & 4.26 & & \\
\hline & \multirow{2}{*}{$\mathrm{Na}_{2} \mathrm{CO}_{3}$} & $\mathrm{ml} / \mathrm{min}$ & 0.3 & 0.6 & 0.7 & 0.8 & $0.9 \#$ & 1.2 & 1.5 & \\
\hline & & p.h $(\mathrm{cm})$ & 2.48 & 3.05 & 3.53 & 4.25 & 5.4 & 4.98 & 4.66 & \\
\hline & \multirow{2}{*}{$\mathrm{RC}_{1}$} & $\mathrm{Cm}$ & 10 & 20 & 30 & 40\# & 50 & 60 & & \\
\hline & & p.h $(\mathrm{cm})$ & 2.46 & 2.95 & 3.66 & 4,5 & 3.73 & 2.9 & & \\
\hline & \multirow{2}{*}{$\mathrm{RC}_{2}$} & $\mathrm{~cm}$ & 20 & 30 & 40 & $50 \#$ & 60 & 70 & & \\
\hline & & p.h(cm) & 3.45 & 4.01 & 4.28 & 4.8 & 4.2 & 3.71 & & \\
\hline & \multirow{2}{*}{$\mathrm{RC}_{3}$} & $\mathrm{~cm}$ & 30 & 40 & 50 & 60 & 70 & 80\# & 90 & 100 \\
\hline & & p.h $(\mathrm{cm})$ & 2.83 & 3.81 & 4.28 & 4.88 & 5.3 & 5.7 & 4.8 & 4.3 \\
\hline & \multirow{2}{*}{$\begin{array}{l}\text { Sample } \\
\text { volume }\end{array}$} & $\mu 1$ & 25 & 50 & 75 & 100 & 125\# & 150 & 175 & \\
\hline & & p.h(cm) & 2.25 & 2.85 & 3.45 & 4.68 & 5.55 & 5.15 & 5.03 & \\
\hline \multirow{8}{*}{ 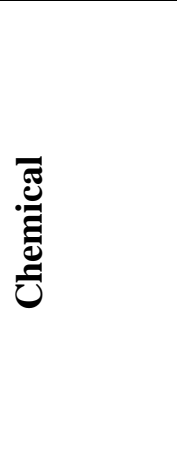 } & \multirow{2}{*}{$\begin{array}{c}\text { Sodium } \\
\text { nitrite (\%) }\end{array}$} & $\mathrm{w} / \mathrm{v} \%$ & 0.2 & 0.4 & 0.6\# & 0.8 & 1.0 & & & \\
\hline & & p.h $(\mathrm{cm})$ & 3.2 & 4.28 & 5.3 & 4.35 & 4.16 & & & \\
\hline & \multirow{2}{*}{$\mathrm{HCl}$} & $\mathrm{mol} / \mathrm{l}$ & 0.1 & 0.2 & 0.3 & $0.4 \#$ & 0.5 & & & \\
\hline & & p.h(cm) & 4.2 & 4.55 & 4.8 & 5.78 & 4.73 & & & \\
\hline & \multirow{2}{*}{$\begin{array}{l}\text { Sulphanilic } \\
\text { acid }\end{array}$} & $\mathrm{w} / \mathrm{v} \%$ & 0.02 & 0.04 & $0.06 \#$ & 0.08 & 0.1 & & & \\
\hline & & p.h $(\mathrm{cm})$ & 4.5 & 5.6 & 6.0 & 5.5 & 5.0 & & & \\
\hline & \multirow{2}{*}{$\mathrm{Na}_{2} \mathrm{CO}_{3}$} & $\mathrm{~mol} / \mathrm{l}$ & 0.05 & 0.1 & 0.15 & $0.2 \#$ & 0.25 & 0.3 & 0.35 & \\
\hline & & p.h $(\mathrm{cm})$ & 5.0 & 5.5 & 5.9 & 6.2 & 6.0 & 5.7 & 5.2 & \\
\hline
\end{tabular}

p.h $=$ peak height

\# = optimize number or best number 


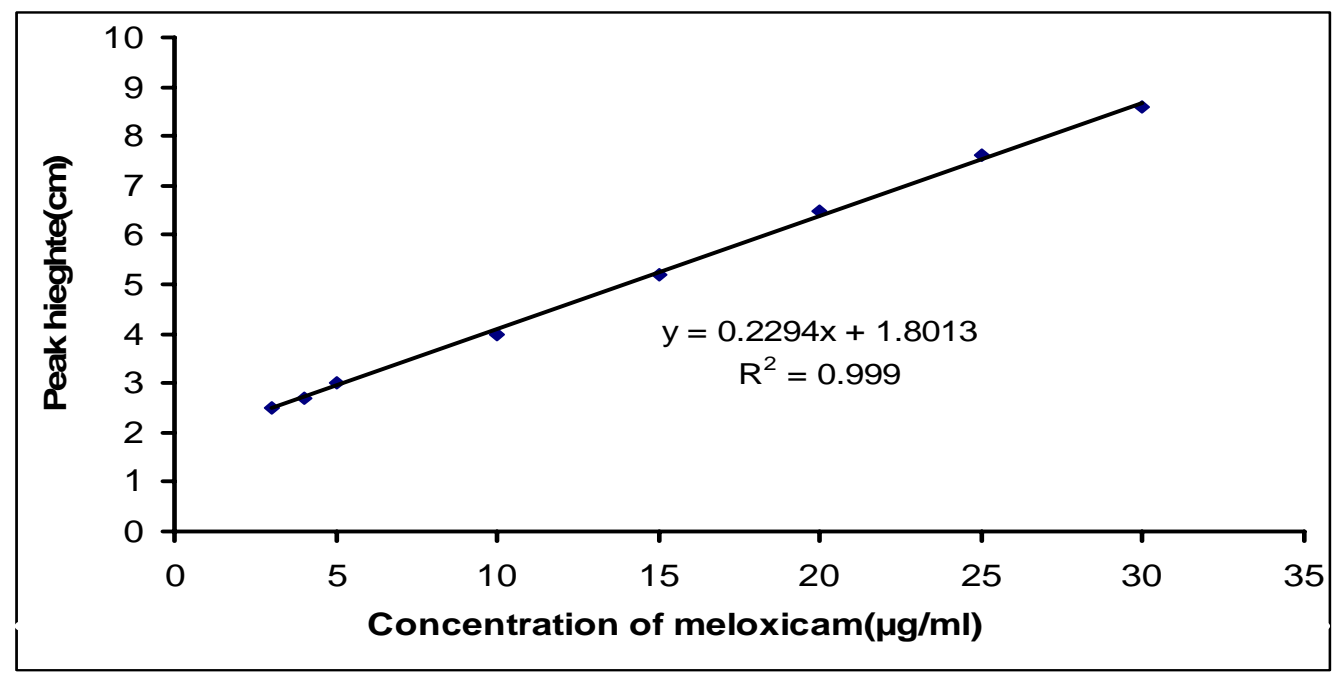

Fig. 9: Calibration curve of FIS determination of Meloxicam by coupling with sulphanilic acid.

Table 6: Statistical data of FIS determination of Meloxicam using diazotization reaction.

\begin{tabular}{|c|c|}
\hline Parameter & Character \\
\hline Linearity range $(\mu \mathrm{g} / \mathrm{ml})$ & $3.0-30$ \\
\hline Detection limit $(\mu \mathrm{g} / \mathrm{ml})$ & 1.0 \\
\hline Correlation coefficient $(\mathrm{r})$ & 0.9994 \\
\hline Sample frequency $(\mathrm{s} / \mathrm{h})$ & 30 \\
\hline
\end{tabular}

\section{Precision and accuracy}

The precision and accuracy data for determination of Meloxicam by FIA using sulphanilic acid as reagent was checked. Table 7 show the values of relative standard deviation (RSD \%) and relative error percent (Erel \%) for triplicate injection of meloxicam at three different concentration levels. Error percent value was within acceptable range $\leq \pm 5 \%$.

Table 7: Accuracy and precision data of the FIS method.

\begin{tabular}{|c|c|c|c|}
\hline Meloxicam conc.( $\mathbf{\mu g} / \mathbf{m l})$ & SD & RSD\% & Error\% \\
\hline 1.0 & 0.05 & 2.0 & +1.52 \\
\hline 15 & 0.05 & 0.9615 & -1.22 \\
\hline 30 & 0.05 & 0.5814 & -1.21 \\
\hline
\end{tabular}

\section{Study of interferences}

Effects of some common foreign species (interferences) which found in tablet formulation were checked, through injecting of synthetic solution containing pure meloxicam and varying amounts of interfering compound, under optimum condition. The result is shows in Table 8 . The tolerable amount that a relative error $(\leq \pm 5 \%)$ varied from a compound to another. 
Table 8: Effect of foreign species on determination of meloxicam.

\begin{tabular}{|c|c|c|c|c|c|}
\hline \multicolumn{3}{|c|}{ Batch method } & \multicolumn{3}{|c|}{ Flow -injection method } \\
\hline Foreign species & Conc.( $\mu \mathrm{g} / \mathrm{ml})$ & $\mathbf{E}_{\text {rel }} \%$ & Foreign species & Conc. $(\mu \mathrm{g} / \mathrm{ml})$ & $\mathbf{E}_{\text {rel }} \%$ \\
\hline Dextrin & 10 & 2.09 & Dextrin & 20 & -1.16 \\
\hline Glucose & 160 & 0.96 & Glucose & 160 & -2.51 \\
\hline Lactose & 80 & -3.59 & Lactose & 80 & +1.38 \\
\hline $\begin{array}{c}\text { Potassium } \\
\text { chloride }\end{array}$ & 80 & -1.88 & $\begin{array}{l}\text { Potassium } \\
\text { chloride }\end{array}$ & 120 & +1.13 \\
\hline Potassium citrate & 20 & 1.39 & $\begin{array}{c}\text { Potassium } \\
\text { citrate }\end{array}$ & 40 & +2.8 \\
\hline Sodium acetate & 40 & 0.68 & Sodium acetate & 80 & -4.09 \\
\hline Sodium chloride & 240 & -3.9 & Sodium chloride & 240 & -1.57 \\
\hline Sorbitol & 160 & 1.79 & Sorbitol & 200 & +2.29 \\
\hline Starch & 40 & 2.35 & Starch & 80 & -3.46 \\
\hline
\end{tabular}

\section{Application of the methods}

The proposed flow injection spectrophotometric methods were applied for Meloxicam determination in tablets. A comparison was made between results obtained by the proposed methods and HPLC method as a standard method, when samples were analyzed by Awamedica Company for drugs. The obtained data were in a good agreement with those obtained by standard method and the labeled amounts, as shown in Table 9.

Table 9: Determination of meloxicam in commercial drugs by batch and FIA method .

\begin{tabular}{|c|l|c|c|c|c|c|c|c|}
\hline Formulation & Composition & $\begin{array}{c}\text { Content } \\
\text { (mg) } \\
\text { declared }\end{array}$ & $\begin{array}{c}\text { Found } \\
\text { (mg) in } \\
\text { batch } \\
\text { method }\end{array}$ & $\begin{array}{c}\text { Recovery } \\
\text { \% }\end{array}$ & $\begin{array}{c}\text { Found } \\
\text { (mg) in } \\
\text { FI } \\
\text { method }\end{array}$ & $\begin{array}{c}\text { Recovery } \\
\text { \% }\end{array}$ & $\begin{array}{c}\text { Standard } \\
\text { method }\end{array}$ & $\begin{array}{c}\text { Recovery } \\
\text { \% }\end{array}$ \\
\hline Loxim & Meloxicam & 7.5 & 7.165 & 95.53 & 7.2 & 96.0 & 7.38 & 98.4 \\
\hline Neopharma & Meloxicam & 7.5 & 7.1645 & 95.52 & 7.25 & 96.6 & 7.58 & 101.1 \\
\hline $\begin{array}{c}\text { Niche } \\
\text { Generics }\end{array}$ & Meloxicam & 15 & 14.95 & 99.66 & 14.95 & 99.6 & 15.0 & 100.0 \\
\hline Mobic & Meloxicam & 15 & 15.14 & 100.9 & 14.4 & 96.0 & 14.68 & 97.9 \\
\hline
\end{tabular}

\section{CONCLUSION}

In this paper meloxicam was reacted as azo-coupling with sulphanilic acid in alkaline medium and has spectrophotometric characteristics suitable for application to the determination of the drug by batch and FI techniques. The batch and FI spectrophotometric methods proposed for quantitative determination of meloxicam in pharmaceutical formulations have the advantage of being fast, simple, inexpensive and applicable over a wide concentration range with good precision and accuracy. 


\section{REFERENCES}

Al-Kindy, S. M. Z.; Suliman, F. E. O.; Al-Habsy, S. ; Al-Lawati, H. (2010). Determination of Meloxicam and Flufenamic Acid in Pharmaceutical Formulations and Biological Fluids using Lanthanide Sensitized Luminescence. International conference and Exhibition on Analytical and Bioanalytical Techniques

Arayne, M. S.; Sultana, N. ; Siddiqui, F. A. (2005). A new RP-HPLC method for analyses of meloxicam in tablets, J. Pharma. Sci., 18, 58-62.

Bandarkar, F. S. ; Vavia, P. R. (2009). A stability indicating HPLC method for the determination of meloxicam in bulk and commercial formulations, J. Pharma. Research, 8, 257-264.

Basu, S. K. ; Sanchita M. (2009). Spectrophotometric methods for the estimation of meloxicam in dosage forms, Asian J. Chem., 21, 5184-5188

British Pharmacopoeia, (2009). Pharma. 4th edn., Press London, 3768p.

Garcia,M. S.; Sanchez-Pedreno, C.; Albero, M. I. ; Marti, J. (2000). Spectrophotometric methods for determining Meloxicam in pharmaceuticals using batch and flowinjection procedures, J. Pharma. Sci., 9, 311-316.

Liu, H.; Zhang, L.; Hao, Y.; Wang, Q.; He, P. ; Fang, Y. (2005). Flow-injection chemiluminescence determination of meloxicam by oxidation with $\mathrm{N}$ bromosuccinimide. Analytica. Chimica. Acta., 541, 187-192.

Murarasu , A. E.; Mandrascu, M. A.; ŞPAC, F. ; Dorneanu, V. (2010). A turbidimetric method for the assay of meloxicam using molybdophosphoric acid, FARMACIA, 58, 315-321.

Nemutlu, E. ; Kır, S. (2004). Validated determination of meloxicam in tablets by using uv spectrophotometry. J. Faculty of Pharmacy, 24, 13-24.

Nemutlu, E.; Sayın, F. ; Başcı, N. E. ; Kır, S. (2007). A validated HPLC method for the determination of meloxicam in pharmaceutical preparations. Hacettepe University J. Faculty of Pharmacy, 27, 107-118.

Sawant, R.; Joshi, R. ; Kawade, D. ; Sarode, V. (2010). Development and validation of spectrophotometric methods for simultaneous estimation of paracetamol and meloxicam in pure and tablet dosage form, Der Pharmacia Lettre, 2, 471-478.

Sinha, P. K.; Jeswanil, R. M.; Topagi, K. S. ; Damle, M. C. (2009). A validated RP-HPLC method for determination of Meloxicam in the Presence of its Impurities. J. Pharm. Tech. Research, 1, 1051-1060.

Taha, E. A.; Salama,N. N. ; El-Sayed, A. L. (2006). Spectrofluorometric and spectrophotometric stability indicating methods for determination of same oxicams using 7-chloro-4-nitrobenzen-2-oxa-1,3-diazol (NBD-Cl), Chem. Pharma. Bull., $54,653-658$.

Zawilla, N. H.; Mohammad, M. A.; El kousy, N. M. ; El-Moghazy Aly, S. M. (2003). Determination of meloxicam in bulk and pharmaceutical formulations. J. Pharma. and Biome. Anal., 32, 1135- 1144.

Zhang, H. ; Hoo-Kyun Choi, (2008). Analysis of meloxicam by high-performance liquid chromatography with cloud-point extraction. Analytical and Bioanalytical Chemistry, 392, 947-953. 